\title{
Invasive Listeriosis
}

National Cancer Institute

\section{Source}

National Cancer Institute. Invasive Listeriosis. NCI Thesaurus. Code C116808.

A bacterial infection by Listeria monocytogenes in a sterile body compartment. 